\title{
REVITALISASI BUDAYA LOKAL KOTA KUDUS DALAM PENGEMBANGAN BAHAN AJAR DI SEKOLAH DASAR
}

\author{
Mutohhar $^{1)}$, Imaniar Purbasari ${ }^{2)}$, Nur Fajrie ${ }^{3)}$ \\ ${ }^{1}$ Pendidikan Bahasa Inggris FKIP Universitas Muria Kudus \\ ${ }^{2}$ PGSD FKIP Universitas Muria Kudus \\ imaniar_purbasari@yahoo.com \\ ${ }^{3}$ PGSD FKIP Universitas Muria Kudus \\ fajrieumk@gmail.com
}

\begin{abstract}
Abstrak
Perwujudan budaya lokal terdapat pada tradisi, religi, sosial, teknologi dan seni. Penelitian ini bertujuan memberikan model pelestarian budaya melalui dunia pendidikan untuk mengembangkan visualisasi yang baru terhadap karakter-karakter budaya lokal di Kudus dengan cara melakukan kajian ilmu pengetahuan dan seni, melalui rekonstruksi serta melakukan visualisasi ulang terhadap karakter budaya lokal dengan gaya visual dan cerita yang baru agar bisa diterima khususnya oleh siswa-siswa di Sekolah Dasar. Jenis metode penelitian ini yang digunakan adalah metode Penelitian dan Pengembangan (Research and Development atau $R \& D$ ). Hasil yang dikembangkan dalam pengembangan bahan ajar terdiri dari: (1) Kajian tentang kondisi, persepsi dan kebutuhan bahan ajar berupa cerita bergambar budaya lokal Kudus; (2) Kajian hasil pengembangan bahan ajar berupa cerita bergambar budaya lokal kota Kudus, dan (3) Kajian hasil uji coba produk.Selama proses pembelajaran budaya lokal Kudus, hasil penilaian sikap diambil dari kemampuan kognitif dan psikomotorik melalui keaktifan siswa dan hasil pengamatan siswa. Aspek kognitif yang dimiliki yaitu pengetahuan tentang cerita budaya lokal Kudus, mennganalisis cerita budaya lokal Kudus dari segi makna yang terkandung
\end{abstract}

\section{Kata Kunci : Budaya lokal, Bahan Ajar, Kota Kudus}

\begin{abstract}
Embodiments of the local culture found in tradition, religious, social, technology and art. This study aims to provide a model of cultural preservation through education to develop new visualization of the characters in the Kudus local culture in a way to study science and art, through reconstruction and visualization on the character of the local culture with the visual style and a new story that acceptable, especially by students in elementary school. This type of research method used Research and Development (Research and Development or R \& D). The results developed in the development of teaching materials consist of: (1) The study of the conditions, perceptions and needs of teaching materials in the form of a picture story of the Kudus local culture; (2) The study of the development of teaching materials in the form of a picture story of Kudus local culture, and (3) study the test results product. Kudus local cultural learning process, the result
\end{abstract}


of attitude assessment drawn from cognitive and psychomotor abilities through student activity and student observations. Cognitive Aspects held that knowledge of Kudus local culture stories, analized Kudus local culture tory in terms of the meaning contained

Keywords: Local Cultures, Materials, Kudus

\section{PENDAHULUAN}

Seiring dengan kemajuan jaman, tradisi dan budaya lokal yang pada awalnya dipegang teguh, dipelihara dan dijaga keberadaannya, kini hampir tinggal cerita. Kebanyakan masyarakat memilih untuk mengedepankan dan daerahnya sendiri yang sesungguhnya justru budaya daerah atau budaya lokal yang sangat sesuai dengan kepribadian bangsanya.

Membahas budaya lokal, secara pengertian luas dikatakan oleh Judistira (2008:113) bahwa budaya lokal bukan hanya terungkap dari bentuk dan pernyataan rasa keindahan melalui kesenian belaka; tetapi termasuk segala bentuk, dan cara-cara berperilaku, bertindak, serta pola pikiran yang berada jauh dibelakang apa yang tampak tersebut. Merebaknya budaya mancanegara yang dikemas dengan media komunikasi membuat keberadaan budaya lokal mudah dilupakan oleh generasi muda di Indonesia. Budaya dari luar negeri menjadi konsumsi publik yang dianut oleh para generasi muda umumnya pada tingkat pelajar. Setidaknya langkah awal untuk usaha mengenalkan budaya-budaya daerahnya sendiri harus diupayakan dengan konsep penyampaian di bidang pendidikan yang mudah diterima oleh generasi penerus.. Salah satu usaha untuk melestarikan budaya lokal melalui sumber belajar dalam bidang pendidikan yang harapannya dapat memberikan pemahaman tentang hasil-hasil budaya setempat kepada peserta didik. Keberlangsungan itu ditandai oleh pewarisan budaya dan karakter yang telah dimiliki masyarakat dan bangsa. Oleh karena itu, pendidikan adalah proses pewarisan budaya dan karakter bangsa bagi generasi muda dan juga proses pengembangan budaya dan 
karakter bangsa untuk peningkatan

kualitas kehidupan masyarakat dan bangsa di masa mendatang.

Budaya lokal di Kota Kudus

terbentuk oleh sejarah asal usul dan

perkembangannya yang di dasari

perjuangan penyebaran agama

islam di pulau Jawa. Perwujudan

budaya lokal terdapat pada tradisi,

religi, sosial, teknologi dan seni.

Dalam perkembangan budaya di

Kota Kudus menjelma menjadi

Kabupaten dagang dan industri.

Peninggalan-peninggalan sejarah

dan benda cagar budaya yang

berhubungan dengan ajaran hindu-

islam yang ada di pulau Jawa

terdapat di Kota Kudus Salam

(1977:5). Sumber materi belajar

itulah dijadikan ciri khas yang

berbeda dengan daerah lain dan

perlu diangkat menjadi bahan

pembelajaran mengenai

pengenalan budaya lokal Kudus

terhadap generasi muda khususnya

siswa-siswa Sekolah Dasar.

Mengenalkan hasil-hasil budaya

kepada peserta didik di ruang

lingkup bidang pendidikan juga

memerlukan strategi pembelajaran

yang sesuai berupa media dan

metode dengan tingkat perkembangan siswa Sekolah

Dasar.

Hubungan antara

keberadaan budaya lokal dengan peran pendidikan harus diaplikasikan dalam kurikulum. Kurikulum tahun 2013 yang selama ini mengacu pada pendekatan scientific, artinya mendekatkan sumber lingkungan dalam aktivitas belajar kepada siswa. Sebagai a plan for learning, kurikulum harus direncanakan untuk dipelajari siswa serta harus diletakkan dalam segala pengalaman dan pengaruh yang ada dalam lingkungan sekitar siswa.

Pendidikan seperti sifat sasarannya yaitu manusia. mengandung banyak aspek dan sifatnya sangat kompleks. Sebagai transformasi budaya, pendidikan diartikan sebagai kegiatan pewarisan budaya dari generasi satu ke generasi yang lain. Sebagai proses pembentukan pribadi, pendidikan diartikan sebagai kegiatan suatu kegiatan yang sistematis dan sistemik terarah kepada terbentuknya kepribadian peserta didik (Tirtarahardja, 2005). 
Terkait dengan usaha pelestarian budaya lokal dalam bidang pendidikan, disamping peran kurikulum, tidak lepas juga dari peran guru sebagai pelaku konsep dalam kurikulum untuk peserta didiknya. Dalam proses pendidikan, guru tidak hanya menjalankan fungsi alih ilmu pngetahuan (transfer of knowledge) tapi juga berfungsi untuk menanamkan nilai (value) serta membangun karakter (Character Building) peserta didik secara berkelanjutan dan berkesinambungan. Untuk itu perlu pengembangan bahan ajar yang bertujuan mengaplikasikan budaya lokal Kudus dalam komponen pembelajaran melalui bahan ajar di Sekolah Dasar. Zulkarnaini (2009) menjelaskan bahan ajar merupakan segala bentuk bahan yang digunakan membantu guru atau instruktur dalam melaksanakan kegiatan belajar mengajar di kelas.

Apabila kita lihat kondisi saat ini, media cerita dan gambar sudah menjadi bahan umum yang menjangkau seluruh tingkatan usia, tidak hanya anak-anak tetapi juga orang dewasa. Metode bercerita membantu kita untuk "melihat" di mana, bagaimana dan apa yang di alami oleh pelaku cerita dari awal sampai akhir kejadian atau kegiatan yang dia alami. Zaman dahulu cerita dapat dituturkan secara lisan. Seiring dengan perjalanannya, cerita-cerita dituangkan ke dalam tulisan yang kita kenal dengan karangan. Sedangkan gambar (visual) dikenal sebagai buatan manusia berupa karya dua dimensi, yang mempunyai kemiripan dengan suatu obyek biasanya obyeknya fisik atau manusia.

Media cerita bergambar dapat menirukan suatu objek dimana objek tersebut menjadi perilaku cerita dalam suatu kegiatan atau kejadian. Menurut Sadiman (2008:28) klasifikasi media pembelajaran mempunyai karakteristik yang dilihat dari kemampuan membangkitkan rangsangan indera penglihatan, pendengaran, perabaan, pengecapan maupun penciuman atau sesuai dengan tingkat hirarki belajar. Media pembelajaran cerita bergambar berupa teks dan gambar membantu menyampaikan 
pembelajaran untuk siswa di Sekolah Dasar.

Dengan dasar penjelasan tersebut melatarbelakangi peneliti untuk merevitalisasi budaya lokal Kudus untuk mengembangkan bahan ajar di Sekolah Dasar. Penelitian ini bertujuan memberikan model pelestarian budaya melalui dunia pendidikan untuk mengembangkan visualisasi yang baru terhadap karakterkarakter budaya lokal di Kudus dengan cara melakukan kajian ilmu pengetahuan dan seni, melalui rekonstruksi serta melakukan visualisasi ulang terhadap karakter budaya lokal dengan gaya visual dan cerita yang baru agar bisa diterima khususnya oleh siswasiswa di Sekolah Dasar.

\section{METODE}

Jenis metode penelitian ini yang digunakan adalah metode Penelitian dan Pengembangan (Research and Development atau $R \& D)$. Penelitian Pengembangan (Research and Development atau $R \& D) \quad$ digunakan peneliti bermaksud menghasilkan produk tertentu, sekaligus menguji keefektifan produk tersebut. Dalam penelitian pengembangan ini menggunakan model prosedural yang mendeskripsikan tahapan yang harus diikuti untuk menghasilkan produk bahan ajar berupa media cerita bergambar.

Untuk tahap awal penelitian, peneliti menggunakan pendekatan kualitatif dengan tujuan memperoleh data faktual di lapangan penelitian. Alasannya adalah permasalahan penelitian ini bersifat holistik (menyeluruh), kompleks, bermakna dan dinamis.Penelitian ini diterapkan pada guru kelas Sekolah Dasar di Kabupaten Kudus yang diharapkan dapat mengaplikasikan perencanaan pembelajaran IPS (Ilmu Pengetahuan Sosial) kepada siswa Sekolah Dasar. Model penelitian pengembangan yang telah dikembangkan oleh peneliti, dengan tiga tahap yaitu : Tahap studi pendahuluan, tahap pengembangan dan tahap validasi.

\section{HASIL PENELITIAN DAN PEMBAHASAN}


Tahap pembahasan akan disajikan hasil studi pendahuluan dan hasil pengembangan. Secara berurutan disajikan: (1) Kajian tentang kondisi, persepsi dan kebutuhan bahan ajar berupa cerita bergambar budaya lokal Kudus; (2) Kajian hasil pengembangan bahan ajar berupa cerita bergambar budaya lokal kota Kudus, dan (3) Kajian hasil uji coba produk.

Secara umum kondisi pelaksanaan pembelajaran di Sekolah Dasar mempunyai hambatan antara lain; (a) tidak adanya acuan atau arahan pembelajaran di Sekolah Dasar mengenai budaya lokal di Kota Kudus sebelumnya; (b) guru kelas Sekolah Dasar yang tidak mempunyai latar belakang kemampuan dalam pembelajaran mengenai budaya lokal kota Kudus; (c) kurang tersedianya media pembelajaran berupa cerita bergambar budaya lokal Kota Kudus dan (d) Guru belum mampu mengembangkan media, materi dan evaluasi pembelajaran untuk budaya lokal Kota Kudus.
Pada tahap hasil
pengembangan bahan ajar cerita bergambar budaya lokal Kudus melalui tahap perencanaan meliputi studi lapangan di lokasi budaya Kabupaten Kudus. Selanjutnya dikumpulkan sumber rujukan untuk pengembangan bahan ajar budaya lokal Kudus. Setelah mengumpulkan data dilapangan dan sumber rujukan dibuatlah perencanaan peta kedudukan bahan ajar meliputi (a) pengelompokan jenis-jenis budaya lokal Kudus, (b) mengaitkan sumber lapangan dan sumber rujukan berupa literature dalam materi bahan ajar, (c) menginterprestasi sumber bahan ajar, (d) membuat sinopsis bahan ajar, dan (e) membuat rancangan cerita bergambar.

Perencanaan bentuk bahan ajar disusun berupa (1) pengenalan materi dan pemahaman materi, (b) rancangan dasar gambar meliputi unsur-unsur desain, efek cerita bergambar, latar belakang dan tokoh, (c) penyusunan dan penyesuaian kompetensi inti serta kompetensi dasar, bahan kepustakaan maupun pedoman 
penggunaan dalam pembelajaran di

Sekolah Dasar. Untuk tahap pelaksanaan terdiri dari analisis kompetensi inti dan kompetensi dasar, penyusunan jaringan materi dan penyusunan bahan ajar. Pada tahap ujicoba draft bahan ajar menghasilkan berbagai konsep dalam pembelajaran yang dilakukan di SD Demaan 3 Kudus meliputi (a) mengidentifikasi unsur-unsur budaya lokal Kudus rupa melalui gambar dan teks cerita menggunakan metode mendongeng serta diskusi; (b) penguasaan bahan ajare dalam gambar dan teks cerita dalam mengekspresikan diri pembelajaran budaya lokal Kudus; (c) menentukan metode dan media yang sesuai dengan karakteristik siswa Sekolah Dasar; (d) kemampuan siswa melalui kepekaan lingkungan.

Sedangkan penguasaan guru dalam pembelajaran budaya lokal Kudus terletak pada: (a) memotivasi siswa untuk merangsang pembelajaran budaya lokal Kudus dalam lingkungan sekitarnya; (b) menghubungkan pembelajaran budaya lokal Kudus dengan kehidupan sehari-hari (kontekstual);(c) membantu mengatasi kesulitan siswa dalam proses pembelajaran lingkungan dan (e) memaknai hasil dari pembelajaran budaya lokal Kudus.

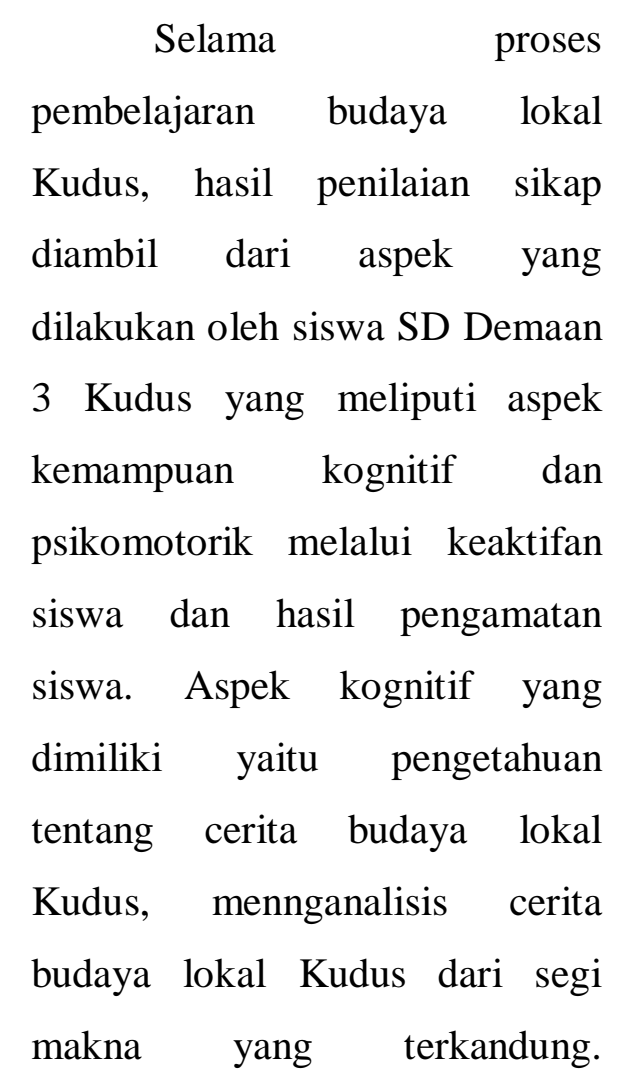
Kemampuan tersebut perlu diimbangi dengan pemahaman tentang konsep dari unsur-unsur budaya dalam suatu cerita di alam sekitarnya.

\section{PENUTUP}


Revitalisasi budaya lokal

Kudus dalam pengembangan

bahan ajar di tingkat Sekolah

Dasar terdiri dari (1) tahap

perencanaan yang meliputi studi

lapangan, pengumpulan sumber

rujukan, perencanaan peta

kedudukan bahan ajar dan

perencanaan bentuk bahan ajar.

Sedangkan tahap pelaksanaan

terdiri dari (1) penganalisis

kompetensi inti dan kompetensi

dasar, penyususna jaringan

materi, penyusunan bahan ajar

budaya lokal Kudus. Pada tahap

ujicoba meliputi aspek

kemampuan kognitif dan

psikomotorik melalui keaktifan

siswa dan hasil pengamatan siswa

\section{DAFTAR PUSTAKA}

Abdullah, Taufik. 2010. Sejarah Lokal di Indonesia. Yogyakarta: Gajahmada Press

Judistira, K. Garna. 2008. Budaya Sunda : Melintasi Waktu Menantang Masa Depan. Bandung : Lemlit Unpad.

Salam, Solichin. 1977. Kudus Purbakala dalam Perjuangan Islam. Kudus: Penertbit Menara Kudus.

Tirtarahardja, Umar, S.L.LA Sulo.2005. Pengantar Pendidikan.

Jakarta:Rineka Cipta.

Zulkarnaini. (2009). Teknik Penyusunan Bahan Ajar. (online). Tersedia : http://zulkarnainidiran. wordpress.com/2009/0 6/28/131/(09

September 2014). 